\title{
コンクリート充填鋼管多層骨組の激震動応答と 崩壊挙動解析に関寸る研究 \\ SEISMIC RESPONSE AND COLLAPSE ANALYSIS \\ OF CONCRETE FILLED STEEL TUBE FRAME
}

\author{
最相元雄* \\ Motoo SAISHO
}

\begin{abstract}
Collapse analysis method of concrete filled steel tube frame (CFT frame) under extraordinary strong ground motion is obtained by the use of the non-dimensional restoring force model of CFT column which is composed of the Tri-linear model and the Clough model. Multi-story CFT frames are designed and the collapse behaviors of them are calculated by the presented analysis method. From the results it is ascertained that the proposed collapse analysis method is useful to calculate multi-story CFT frames. It is also shown that the local buckling and the crack of steel tube of CFT column are closely related to the collapse of CFT frame and they are the basic factors of CFT frame design against strong ground motion.
\end{abstract}

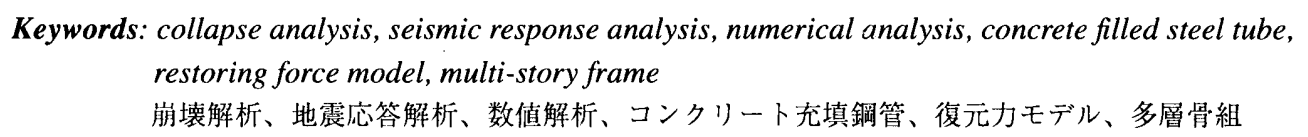

1 序

近年続発した極めて強い地震では数多くの建物崩垍を見た。この 激震動による建物崩壊を防ぐためには建物崩壊挙動を明らかにする ことがまず必要であるが、最近では建物崩壊に関する研究が進めら れ、文献 1)にはこれまでの研究成果がまとめられている。本論でも 地震動による建物崩壊挙動を刘象とするが、これまで検討されなか ったコンクリート充填円形鎙管骨組 (CFT 骨組) の崩壊挙動を対象 とするものである。即ち、既に報告した CFT 柱の復元力モデル 5)-6) を用いて地震応答による骨組崩壊の解析法を導き、これによって数 做解析した結果からCFT 多層骨組の崩壊挙動とともに骨組崩壊を支 配するCFT 柱の損傷について述べる。

CFT 柱は地震力のような動的荷重に対して高い終局耐力と塑性変 形能力を発揮し優れた耐震構造要素としての条件を備えていること を既に報告したが 2)-4)、その復元力特性は、コンクリートと鋼管の 材料特性に支配される他に、CFT 柱固有の鋼管と充填コンクリート 間の相互作用、鋼管の局部座屈と鋼管亀裂の発生、さらには動的荷 重による載荷速度効果等の影響を受けて複雑となり、単純な復元力

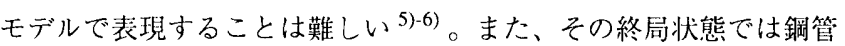
重裂が発生し脆性的な破壊が生じる場合がある。
このため、ここに示す数値解析法はこれら CFT 骨組固有の復元力 特性と脆性的な破壊挙動となる CFT 柱の終局状態を解析し、CFT 多層骨組の地震応答による損傷及び骨組崩壊挙動を求めるものであ る。

\section{CFT 多層骨組の数值解析法}

\section{1 骨組解析モデル}

$\mathrm{CFT}$ 柱と H 形鋼梁の CFT 多層平面骨組を剛体の柱梁接合部パネ ルと両端に弾塑性ヒンジを持つ柱及び梁部材で構成される骨組解析 モデル ( 図 1)で表す。CFT 柱及び H 形鋼梁部材の実験結果による と多くの場合部材端部近くに歪と変形が集中し局部座屈が発生する が、この部材端部と比較して部材中間部の歪と変形は小さい。この 挙動を近似して弾塑性ヒンジ間では軸方向にのみ弾性変形し曲げ変 形とせん断変形は生じないとし、部材の曲げ変形とせん断変形を雨 端の弾塑性ヒンジ回転角のみで表すこととする。

骨組の変形は各柱梁接合部パネル中心の水平変位 $\left(\mathrm{u}_{\mathrm{i}}, \mathrm{i}\right.$ : 柱梁接合 部パネル番号)、鉛直変位 $\left(\mathrm{w}_{\mathrm{i}}\right)$ 及び回転変形角 $\left(\theta_{\mathrm{i}}\right)$ で表わす。骨組 の質量は剛体の柱梁接合部パネルに集中させ、且つ、その剖体内に 一様に分布させる。 


\section{2 弾塑性ヒンジの復元力特性}

CFT 柱の両端に設けた弾塑性ヒンジの復元力特性 (M- $\phi$ 関係) を、 図 2 で説明するように鉛值荷重 $(\mathrm{V})$ と水平荷重 $(\mathrm{H})$ を載荷する网形 鋼管の CFT 柱実験の柱脚曲げモーメント $(\mathrm{M})$ と部材变形角 $\left(\delta_{\mathrm{h}} / \mathrm{l}_{\mathrm{c}}\right)$ の関係で近似し、これを無次元復元力モデル 5)-6) で表す。この復元 カモデルは曲げモーメント $(\mathrm{M})$ と回転変形角 $(\phi)$ を無次元量で表し た $\mathrm{M} / \mathrm{M}_{\mathrm{u}}-\phi / \phi_{\mathrm{u}}\left(\mathrm{M}_{\mathrm{u}}\right.$ : 終局曲げ耐力, $\phi_{\mathrm{u}}: \mathrm{M}_{\mathrm{u}} / \mathrm{K}_{\mathrm{o}}$ の初期值, $\mathrm{K}_{\mathrm{o}}$ : 初期弾性

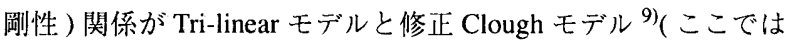
Clough モデルと呼ぶ) を組み合わせたモデルで近似できるとするも ので、各々の骨格曲線を図 3-図 4 の太線で示すように復元力特性値 の初期弾性剛性 $\left(K_{0}\right)^{5)}$ 、降伏曲げ耐力 $\left(M_{y}\right)$ 、終局曲げ耐力 $\left(M_{u}\right)$ で 表す。地震応答中には柱軸力が変動するが、この $\mathrm{M}_{\mathrm{y}}, \mathrm{M}_{\mathrm{u}}$ は各履歴 点で異なる柱軸力に対する值で、文献 3), 5) に示す次の值とする。

降伏曲け耐力 $M_{y}$ は $M_{y s}$ とコンクリート鋼管強度比 $(\rho)$ で表す。

$$
\mathrm{M}_{\mathrm{y}}=\mathrm{M}_{\mathrm{ys}} /(0.19 \rho+0.80)
$$

但し、 $\rho=\sigma_{\mathrm{c}} \mathrm{A}_{\mathrm{c}} / \sigma_{\mathrm{u}} A_{\mathrm{s}}\left(\sigma_{\mathrm{c}}\right.$ : コンクリート压縮強度、 $\sigma_{\mathrm{u}}$ : 鋼管の引張強 さ、 $A_{s}$ : 鋼管断西積、 $A_{c}$ : 充填コンクリート断面積)である。 $M_{y s}$ はコンクリート断面縁応力度がコンクリート圧縮強度 $\left(\sigma_{\mathrm{c}}\right)$ となる三 角形応力度分布、又、鋼管断面縁応力度が鋼管降伏応力度 $\left(\sigma_{y}\right)$ とな る三角形応力度分布を各々コンクリート断面と鋼管断面の応力度分 柯と仮定した場合の一般化累加強度である。

終局曲げ酎力 $\mathrm{M}_{\mathrm{u}}$ はコンクリート拘束効果を考慮した CFT 柱断面 の全塑性応力状態、即ち、断面志力度分布を矩形分布とし、コンク リート応力度を拘束コンクリート压縮強度 $\sigma_{\mathrm{ce}}\left(=(0.76 / \rho+0.76) \sigma_{\mathrm{c}}\right)$ 、 鋼管圧縮応力度を $\sigma_{\mathrm{u}^{\prime}} / \sqrt{3}$ 、鋼管引張灾力度を $2 \sigma_{\mathrm{u}^{\prime}} / \sqrt{3}$ と表した場 合の一般化累加強度で次式の值である ${ }^{3)}$ 。

$$
\begin{aligned}
& \mathrm{M}_{\mathrm{u}}=\mathrm{C}_{\mathrm{c}} \mathrm{M}_{\mathrm{u}}+\mathrm{S}_{\mathrm{u}} \\
& \mathrm{N}=\mathrm{c}_{\mathrm{c}} \mathrm{N}+{ }_{\mathrm{s}} \mathrm{N}
\end{aligned}
$$

ここで、 ${ }_{\mathrm{c}} \mathrm{M}_{\mathrm{u}},{ }_{\mathrm{S}} \mathrm{M}_{\mathrm{u}}$ は全塑性応力状態における各々コンクリートと 鋼管の終局曲げ耐力であり、 ${ }_{\mathrm{c}} \mathrm{N},{ }_{\mathrm{s}} \mathrm{N}$ は同じ态力状態でのコンクリー トと鋼管の軸力を各々表す。又、NはCFT 柱軸力である。

Tri-linear モデルとClough モデルの組み合わせうについては、 CFT 柱の鋼管局部座屈発生前の復元力を Tri-linear モデルで表し局部 座屈発生後の值をClough モデルで表すこととし、鋼管亀裂発生後

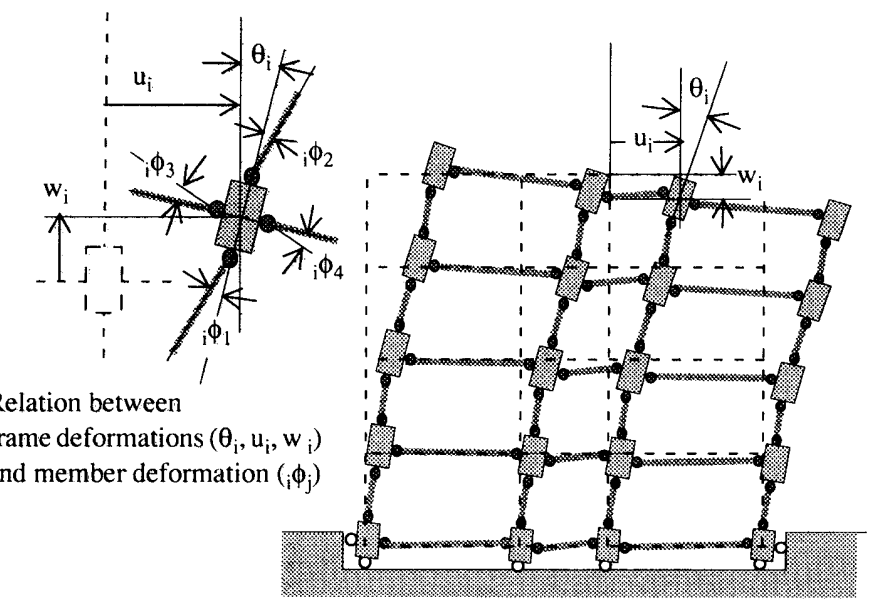

図 1 CFT 骨組の解析モデル

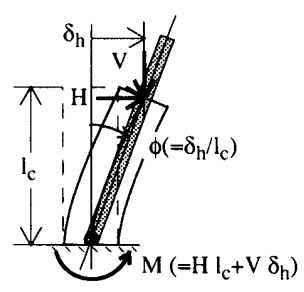

図 2 弾塑性ヒンジの M- $\phi$ 関係と CFT 柱実験值 $\left(\mathrm{H}, \mathrm{V}, \delta_{\mathrm{h}}\right)$

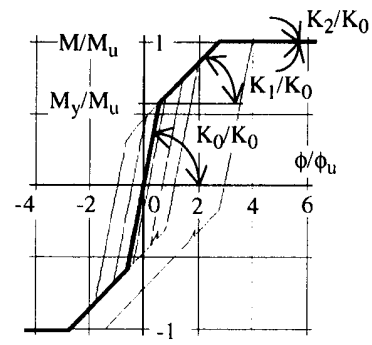

図 3 Tri-linear モデルの骨格曲線 $\left(\mathrm{K}_{1} / \mathrm{K}_{0}=0.2, \mathrm{~K}_{2} / \mathrm{K}_{0}=0.001\right)$

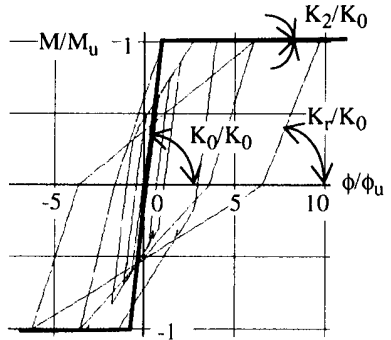

図 4 Clough モデルの骨格曲線 $\left(\mathrm{K}_{2} / \mathrm{K}_{0}=0.001\right)$
には CFT 柱の剛性と復元力は完全に失われるとする。

鋼管の局部座屈と刍裂発生は文献 4)-5)に示した条件式で決定す る。但し、文献 4)-5)では一定軸力柱に適用する場合の条件式とし て表したが、同じ条件式をここでは変動軸力柱に適用する場合の条 件式として表し、これを以下に示す。

鋼管局部座屈については、鋼管の歪振幅が限界値 $\varepsilon_{\mathrm{lb}}\left(=14 \sigma_{\mathrm{u}} / \mathrm{E}, \sigma_{\mathrm{u}}\right.$ : 鋼管の引張強さ， $\mathrm{E}$ : 鋼管のヤング係数 ) に達すると局部座屈すると いう実験結果から得られた局部座屈発生の条件より条件式を求める 5)。これを CFT 柱の塑性変形率 $\mu\left(=\phi_{\mathrm{p}} / \phi_{\mathrm{u}}, \phi_{\mathrm{p}}\right.$ : 望性変形) で表し、局 部座屈発生澍の塑性変形率を $\mu_{\mathrm{LB}}$ とすると、

$$
\mu_{L B}=\frac{1}{1-\cos \theta_{n}} \frac{s \cdot \varepsilon_{l b}}{\beta}+\frac{1+\cos \theta_{T} \beta_{T}}{1-\cos \theta_{n}} \frac{{ }^{\prime}}{\beta} \mu_{T}
$$

上式中、 $M>0$ ( $M$ : 柱脚曲げモーメント) で局部座屈する場合は $s=1 、 M<0$ で局部座屈する場合は $s=-1$ である。又、 $\theta_{n}$ 值は CFT 柱 脚断面の中立軸位置を表し、 $\mu_{\mathrm{T}}, \mathrm{T} \theta_{\mathrm{n}}, \beta_{\mathrm{T}}$ は局部座屈発生以前に鋼管 表面の軸方向引張塑性歪が最大となったときの各々 $\mu, \theta_{\mathrm{n}}, \beta$ 值であ る。但し、 $\beta$ 值は次式の值で、式中の D は鋼管外径である。

$$
\beta=\frac{3}{\left(1-M_{y} / M_{u}\right)\left(2+M_{y} / M_{u}\right)} \frac{D \phi_{u}}{l_{c}}
$$

CFT 柱の鋼管亀裂発生については、鋼管亀裂発生までの CFT 柱の 䇣積塑性変形率 $\mu_{\mathrm{cr}}\left(=\Sigma \Delta \mu_{\mathrm{T}}+\Sigma \Delta \mu_{\mathrm{TC}}\right)$ を表す次式により決定する ${ }^{4)}$ 。 $\sum\left(1+\cos \theta_{n}\right) \beta \Delta \mu_{T}+\sum \frac{\pi t}{2 l_{l b}} \frac{1}{\sqrt{\varepsilon_{a v}}}\left(1-\cos \theta_{n}\right) \beta \cdot \Delta \mu_{T C}=\alpha \varepsilon_{f}$ 但L、 $\varepsilon_{a v}=\sum\left(1-\cos \theta_{n}\right) \beta \cdot \Delta \mu_{T C}$

上式中、 $\mathrm{l}_{\mathrm{lb}}$ : 鋼管の弾性局部座屈長さ、 $\mathrm{t}$ :鋼管厚、 $\Sigma$ は鋼管亀裂 が発生するまでの增分和を表す。 $\Delta \mu_{\mathrm{T}}$ は鋼管亀裂が発生する位置の 鋼管応力が引張応力状態となる場合の柱の塑性変形率增分 $(\Delta \mu)$ であ 

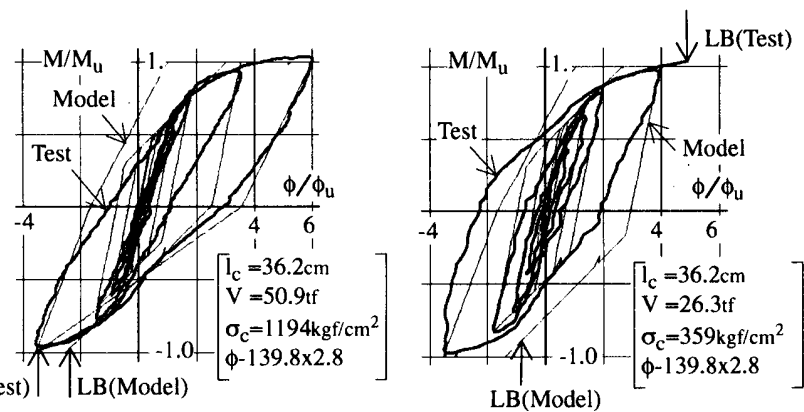

図 5 局部座屈発生までの荷重変形関係 (LB: 鋼管局部座屈発生点)
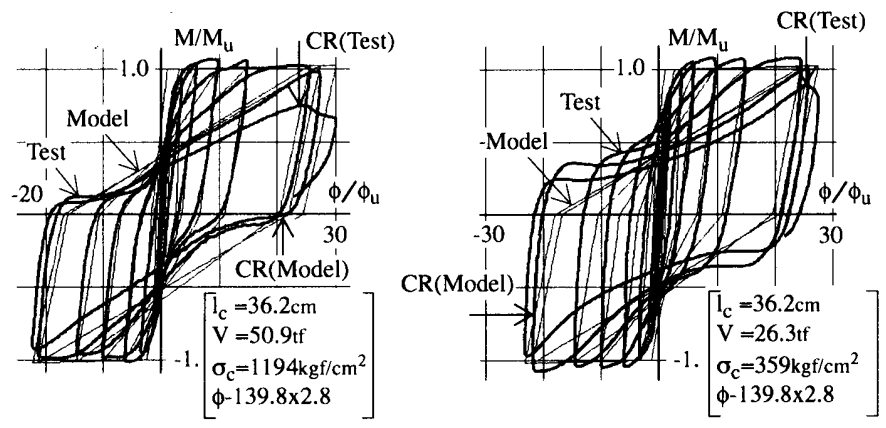

図 6 鋼管亀裂発生までの荷重変形関係 (CR: 鋼管亀裂発生点)

る。同様に、 $\Delta \mu_{\mathrm{TC}}$ は鋼管亀裂が発生する位置が圧縮応力状態とな る場合の柱の塑性変形率増分 $(\Delta \mu)$ である。(5) 式は引張塑性歪の累 積值が $\alpha \varepsilon_{\mathrm{f}}\left(\alpha(=-0.3 p+5.0)\right.$ : 定数, $\varepsilon_{\mathrm{f}}$ : 破断伸び ) に達すると亀裂が発 生するという条件から求めたもので、左辽第 1 項は亀裂発生位置が 引張応力状態での軸方向引張塑性歪の累積值、左辺第 2 項は同位置 が圧縮応力状態で局部座屈変形することにより鋼管表面に発生する 軸方向引張塑性歪の累積値を表す。

図 5- 図 6 にはこの復元力モデルの値を実験値と比較した結果を 再掲して示す5)-6)。図の太線は実験結果で細線は復元力モデルの值 である。単純な復元力モデルであるが、復元力の履歴形状とともに 各復元力特性值も概略近似されている。

-.-万方、 $\mathrm{H}$ 形鋼梁両端の弾塑性ヒンジの復元力特性は $\mathrm{H}$ 形鋼の初 期弾性剛性 $\left(\mathrm{K}_{\mathrm{o}}\right)$ と全塑性モーメント $\left(\mathrm{M}_{\mathrm{p}}\right)$ で定義される Bi-linear モ デルで表す。

\section{3 部材の剛性行列}

図 7 に示すCFT 柱両端の弾塑性ヒンジにおける曲げモーメント $\left(\mathrm{M}_{1}, \mathrm{M}_{2}\right)$ と部材軸力 $(\mathrm{N})$ の増分 $\left(\Delta \mathrm{M}_{1}, \Delta \mathrm{M}_{2}, \Delta \mathrm{N}\right)$ を回転変形增分 $\left(\Delta \phi_{1}\right.$,
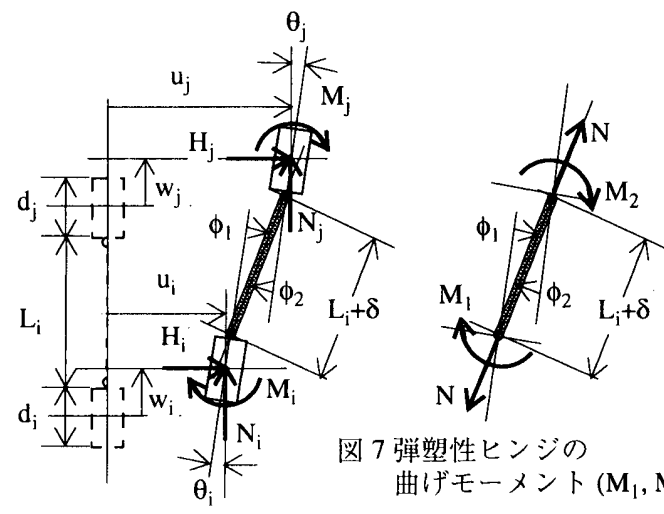

㲸 7 弾塑性ヒンジの 曲げモーメント $\left(\mathrm{M}_{1}, \mathrm{M}_{2}\right)$ と軸力 $(\mathrm{N})$

図 8 CFT 柱と柱梁接合部パネル
$\left.\Delta \phi_{2}\right)$ と軸方向変形増分 $(\Delta \delta)$ で表す。

$$
\{\Delta \mathrm{s}\}=\left[\mathrm{k}_{0}\right]\{\Delta \mathrm{e}\}
$$

ここで $\{\Delta s\}=\left[\Delta \mathrm{M}_{1} \Delta \mathrm{M}_{2} \Delta \mathrm{N}\right]^{\mathrm{T}},\{\Delta \mathrm{e}\}=\left[\Delta \phi_{1} \Delta \phi_{2} \Delta \delta\right]^{\mathrm{T}}$

$$
\left[\mathrm{k}_{0}\right]=\left[\begin{array}{ccc}
k_{1} & 0 & 0 \\
0 & k_{2} & 0 \\
0 & 0 & k_{3}
\end{array}\right]
$$

$\left[\mathrm{k}_{0}\right]$ の各要素 $\mathrm{k}_{1}, \mathrm{k}_{2}$ は弾塑性ヒンジの無次元復力モデルから決定 される回転剛性 $\left(k_{n}=\Delta M_{n} / \Delta \phi_{n}, n=1,2\right)$ であり、 $k_{3}$ は CFT 柱軸方向弾 性剛性である。 $\mathrm{k}_{3}$ の值は部材が引張軸力状態と圧縮軸力状態の場合 で異なり、引張軸力状態ではコンクリート引張強度を無視し鋼管の みの軸方向弾性剛性で $\mathrm{k}_{3}$ を表し、压縮軸力状態では充填コンクリー トと鋼管の軸方向弾性剛性の和で $\mathrm{k}_{3}$ を表す。

次に、CFT 柱両端の弾塑性ヒンジにおける回転変形增分 $\left(\Delta \phi_{1}, \Delta \phi_{2}\right)$ と軸方向変形增分 $(\Delta \delta)$ を図 8 に示す柱梁接合部パネル中心位置の回 転変形增分 $\left(\Delta \theta_{\mathrm{i}}, \Delta \theta_{\mathrm{j}}\right)$ 、水平変位增分 $\left(\Delta \mathrm{u}_{\mathrm{i}}, \Delta \mathrm{u}_{\mathrm{j}}\right)$ 、鉛直変位增分 $\left(\Delta \mathrm{w}_{\mathrm{i}}\right.$, $\Delta \mathbf{w}_{\mathrm{j}}$ )で表すと、

$\{\Delta \mathrm{e}\}=[\mathrm{T}]\{\Delta \mathrm{d}\}$

ここで、 $\{\Delta \mathrm{d}\}=\left[\Delta \theta_{\mathrm{i}} \Delta \theta_{\mathrm{j}} \Delta \mathrm{u}_{\mathrm{i}} \Delta \mathrm{u}_{\mathrm{j}} \Delta \mathrm{w}_{\mathrm{i}} \Delta \mathrm{w}_{\mathrm{j}}\right]^{\mathrm{T}}$ 、 [T] は柱梁接合部パネル 背 $\left(\mathrm{d}_{\mathrm{i}}, \mathrm{d}_{\mathrm{j}}\right)$ 、部材長 $\left(\mathrm{L}_{\mathrm{i}}\right)$ 、初期変形 $\left(\delta, \phi_{1}, \phi_{2}, \theta_{\mathrm{i}}, \theta_{\mathrm{j}}\right)$ で表される変換行 列である。

部材両端の柱梁接合部パネル中心位置に $\left(\mathrm{M}_{\mathrm{i}}, \mathrm{M}_{\mathrm{j}}, \mathrm{H}_{\mathrm{i}}, \mathrm{H}_{\mathrm{j}}, \mathrm{N}_{\mathrm{i}}, \mathrm{N}_{\mathrm{j}}\right)$ が作 用する柱部材 (図 8) の仮想速度式をたてると、

$\{\mathrm{f}\}^{\mathrm{T}}\{\Delta \mathrm{d}\}=\{\mathrm{s}\}^{\mathrm{T}}\{\Delta \mathrm{e}\}$

但し、 $\{\mathrm{f}\}=\left[\mathrm{M}_{\mathrm{j}} \mathrm{M}_{\mathrm{j}} \mathrm{H}_{\mathrm{i}} \mathrm{H}_{\mathrm{j}} \mathrm{N}_{\mathrm{i}} \mathrm{N}_{\mathrm{j}}\right]^{\mathrm{T}}$ である。(8) 式を(9) 式へ代入し、 これが恒等的に成立するための条件より部材力 \{f\}が得られる。

$\{\mathrm{f}\}=[\mathrm{T}]^{\mathrm{T}}\{\mathrm{s}\}$

これより部材力増分 $\{\Delta \mathrm{f}\}$ は

$\{\Delta \mathrm{f}\}=[\Delta \mathrm{T}]^{\mathrm{T}}\{\mathrm{s}\}+[\mathrm{T}]^{\mathrm{T}}\{\Delta \mathrm{s}\}$

右辺の第二項は (6) 式と (8) 式を代入することで

$[\mathrm{T}]^{\mathrm{T}}\{\Delta \mathrm{s}\}=[\mathrm{T}]^{\mathrm{T}}\left[\mathrm{k}_{0}\right][\mathrm{T}]\{\Delta \mathrm{d}\}$

(11) 式の右辺の第一項については、初期変形 $\left(\delta, \phi_{1}, \phi_{2}, \theta_{\mathrm{j}}, \theta_{\mathrm{j}}\right)$ で表 された [T]の各要素の増分を求め、これを代入することにより次式 となる。

$[\Delta \mathrm{T}]^{\mathrm{T}}\{\mathrm{s}\}=[\mathrm{p}]\{\Delta \mathrm{d}\}$

[p] の)各要素は初期応力 $\left(\mathrm{M}_{1}, \mathrm{M}_{2}, \mathrm{~N}\right)$ と初期変形 $\left(\delta, \phi_{1}, \phi_{2}, \theta_{i}, \theta_{j}\right)$ で表 され、部材のP- $\Delta$ 効果を表す。

(12) 式と (13) 式を (11) 式へ代入すると次の部材力増分式となる。

$$
\{\Delta \mathrm{f}\}=[\mathrm{k}]\{\Delta \mathrm{d}\} \quad \text { 但し } \quad[\mathrm{k}]=[\mathrm{p}]+[\mathrm{T}]^{\mathrm{T}}\left[\mathrm{k}_{0}\right][\mathrm{T}]
$$

ここで $[\mathrm{k}]$ は柱梁接合部パネル中心位置での変形増分と部材力增 分の関係を表す CFT 柱の剛性行列である。

なお、変形の大きい挙動となる CFT 骨組崩壊を解析対象とするた め、[T] 及び [p] の各要素は微小項を無視することなく厳密な值で 表すこととする。

（14）式は CFT 柱について導いた部材力増分式であるが、水平成分 と鉛直成分を入れ替えた同様の過程により、柱梁接合部パネル中心 
位置の変形増分で表した梁の部材力増分式が求められる。

\subsection{CFT 多層骨組の剛性行列}

各柱梁接合部パネル中心位置の回転成分、水平方向成分及び鉛直 方向成分の力の釣合条件と変形の連続条件より、図 1 の解析モデル で示した CFT 多層骨組の浻性行列 [K] が求められ、骨組の各柱梁接 合部パネル中心位置に作用する荷重増分 $\{\Delta \mathrm{F}\}$ とその点の回転変形 増分及び変位增分 $\{\Delta \mathrm{D}\}$ の関係式が $(15)$ 式となる。

$\{\Delta \mathrm{F}\}=[\mathrm{K}]\{\Delta \mathrm{D}\}$

但 $L 、\{\Delta \mathrm{F}\}=\left[\ldots \Delta \overline{\mathrm{M}}_{\mathrm{i}} \ldots \Delta \overline{\mathrm{H}}_{\mathrm{i}} \ldots \Delta \overline{\mathrm{N}}_{\mathrm{i}} \ldots\right]^{\mathrm{T}}$

$\{\Delta \mathrm{D}\}=\left[\ldots \Delta \theta_{\mathrm{i}} \ldots \Delta \mathrm{u}_{\mathrm{i}} \ldots \Delta \mathrm{w}_{\mathrm{i}} \ldots\right]^{\mathrm{T}}$

上式中、 $\overline{\mathrm{M}}_{\mathrm{i}}, \mathrm{H}_{\mathrm{i}}, \overline{\mathrm{N}}_{\mathrm{i}}$ は $\mathrm{i}$ 節点の柱梁接合部パネル中心位置に作用す る回転成分、水平方向成分及び鉛直方向成分の節点荷重である。

この $[\mathrm{K}]$ を用いると CFT 多層骨組の增分型振動方程式は (16) 式と なる。

$[M]\{\Delta \ddot{D}\}+[C]\{\Delta \dot{D}\}+[K]\{\Delta D\}=-[M]\left\{\Delta \ddot{D}_{g}\right\}$ (16)

但し、 $[\mathrm{M}]$ : 質量行列、 $[\mathrm{C}]$ : 減衰行列、 $\left\{\mathrm{D}_{\mathrm{g}}\right\}$ : 地震動ベクトル、ド ットは時間に関する微分を表す。

\section{CFT 多層骨組の設計}

骨組崩壊解析に用いるCFT 骨組を設計する。骨組は CFT 柱と H 形鋼梁で構成される 15 層 3 スパン (FL15-3, FS15-3) と7 層 3 スパン (FL7-3, FS7-3) の多層平面骨組で、いずれの骨組も階高 4m、外スパ ン長 $8 \mathrm{~m}$ 、内スパン長 $6 \mathrm{~m}$ とし、各層の重量 $(\mathrm{w})$ は等しく $\mathrm{w}=200 \mathrm{tf}$ と する。又、各々の骨組は普通強度コンクリート充填鋼管柱の骨組 (FL15-3，FL7-3) と超高強度コンクリート充填鋼管柱の骨組 (FS15-3, FS7-3)の 2 種類とする。文献 7)-8)の設計方法を参考に次の条件を 与えてこれらの CFT 骨組を設訫する。

i) 各層の柱せん断耐力分布は $\mathrm{A}_{\mathrm{i}}$ 值（建築基準法施行令に基づく 建設省告示) で規定される地震層せん断力分布と一致する。

ii) 最上層を除き全ての柱梁接合部における柱梁終局曲げ耐力比 (COF) を等しく $\mathrm{COF}=1.5$ とする。

iii) 層せん断力分布が $\mathrm{A}_{\mathrm{i}}$ 值で表す分布と一致する水平荷重を作 用させた場合の骨組の終局水平耐力をベースシアー係数で 0.25 とす る。この終局水平耐力は、骨組の最上層を除く全ての梁雨端と第一 層柱脚と最上層柱頭に塑性ヒンジが形成される崩壊機構を仮定した 極限解析によって求める。

iv) $\mathrm{CFT}$ 柱の復元力特性がコンクリート鋼管強度比 $\rho\left(=\sigma_{c} A_{c} / \sigma_{u} A_{s}\right)$

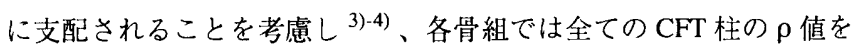
等しくFL15-3, FL7-3 では $\rho=1 、 F S 15-3, F S 7-3$ では $\rho=4$ とする。

v) $\mathrm{H}$ 形鋼梁には $r_{x}{ }^{2} / A=4.0\left(r_{x}\right.$ : 強軸回りの断面 2 次半径、 $A$ : 断面 積 )の関係が成立する ${ }^{7)}$ 。

なお、 $\mathrm{CFT}$ 柱の鋼管及び $\mathrm{H}$ 形鋼梁の材料特性値は $\sigma_{\mathrm{u}}=4.50 \mathrm{tf} / \mathrm{cm}^{2}$, $\sigma_{\mathrm{y}}=3.50 \mathrm{tf} / \mathrm{cm}^{2}\left(\sigma_{\mathrm{u}}\right.$ : 鋼管引張強さ, $\sigma_{\mathrm{y}}$ : 鋼管及び $\mathrm{H}$ 形鋼梁の降伏応力 度) とし、コンクリート压縮強度 $\left(\sigma_{\mathrm{c}}\right)$ は普通強度コンクリートで $\sigma_{\mathrm{c}}=300 \mathrm{kgf} / \mathrm{cm}^{2}$ (FL15-3, FL7-3) 、超高強度コンクリートで $\sigma_{\mathrm{c}}=1200 \mathrm{kgf} / \mathrm{cm}^{2}(\mathrm{FS} 15-3, \mathrm{FS7} 7$-3) とする。鋼管断面は自由に選べると して設計した結果を表 1 - 表 4 に示す。これらの骨組を 2.1 節で説明 した骨組解析モデル（図 1) で表し第 1 次固有周期求めると、1.98 秒
(FL15-3), 1.56 秒 (FL7-3), 1.96 秒 (FS15-3), 1.56 秒 (FS7-3) となる。

\section{4. 単調水平荷重を受ける骨組挙動}

比例水平荷重を単調に静載荷した場合の CFT 骨組 (FL15-3, FL7-3, FS15-3, FS7-3) の弾塑性挙動を (15) 式を用いて解析し、各 CFT 多層 骨組の基本的な復元力特性と変形性状を示す。

骨組の荷重は柱梁接合部パネル中心位置にのみ作用するとし、自

表 1 FL15-3 Frame $\left(\sigma_{\mathrm{c}}=300 \mathrm{kgf} / \mathrm{cm}^{2}\right)$

\begin{tabular}{|c|c|c|c|c|c|c|c|c|}
\hline \multirow{3}{*}{ Story } & \multicolumn{2}{|c|}{ Steel tube of CFT column } & \multicolumn{4}{|c|}{ H-section beam } & \multicolumn{2}{|c|}{ Axial force ratio } \\
\hline & Outside column & Inside column & \multicolumn{2}{|c|}{ Outside beam } & \multicolumn{2}{|c|}{ Inside beam } & \multirow{2}{*}{$\begin{array}{l}\text { Outside } \\
\left(\mathrm{N} / \mathrm{N}_{\mathrm{u}}\right)\end{array}$} & \multirow{2}{*}{$\begin{array}{c}\text { Inside } \\
\left(\mathrm{N} / \mathrm{N}_{\mathrm{u}}\right)\end{array}$} \\
\hline & $(D \times t)$ & $(\mathrm{D} \times \mathrm{t})$ & $\mathbf{I}_{\mathrm{x}}$ & $\overline{\mathrm{Z}_{\mathrm{p}}}$ & $\mathrm{I}_{\mathrm{x}}$ & $\mathrm{Z}_{\mathrm{P}}$ & & \\
\hline $\begin{array}{l}1 \\
2 \\
3 \\
4 \\
5\end{array}$ & \begin{tabular}{|l}
$723 \times 11.5$ \\
$719 \times 11.4$ \\
$714 \times 11.3$ \\
$707 \times 11.2$ \\
$699 \times 11.1$
\end{tabular} & \begin{tabular}{|l|}
$873 \times 13.9$ \\
$867 \times 13.8$ \\
$860 \times 13.7$ \\
$852 \times 13.5$ \\
$842 \times 13.4$
\end{tabular} & $\begin{array}{l}5.10 \\
4.96 \\
4.79 \\
4.59 \\
4.35\end{array}$ & $\begin{array}{l}1.35 \\
1.32 \\
1.29 \\
1.25 \\
1.20\end{array}$ & $\begin{array}{l}3.48 \\
3.38 \\
3.27 \\
3.13 \\
2.97\end{array}$ & $\begin{array}{l}1.01 \\
0.99 \\
0.97 \\
0.94 \\
0.90\end{array}$ & $\begin{array}{l}0.24 \\
0.22 \\
0.21 \\
0.20 \\
0.19\end{array}$ & \begin{tabular}{|l|}
0.28 \\
0.27 \\
0.25 \\
0.24 \\
0.22
\end{tabular} \\
\hline $\begin{array}{r}6 \\
7 \\
8 \\
9 \\
10\end{array}$ & $\begin{array}{l}689 \times 1 \\
678 \times 1 \\
664 \times 1 \\
648 \times 1 \\
629 \times 1\end{array}$ & $\begin{array}{l}829 \times 13.2 \\
815 \times 12.9 \\
799 \times 12.7 \\
779 \times 12.4 \\
756 \times 12.0\end{array}$ & $\begin{array}{l}4.08 \\
3.77 \\
3.44 \\
3.07 \\
2.68\end{array}$ & $\begin{array}{l}1.14 \\
1.08 \\
1.00 \\
0.92 \\
0.83\end{array}$ & $\begin{array}{l}2.78 \\
2.57 \\
2.34 \\
2.09 \\
1.82\end{array}$ & $\begin{array}{l}0.86 \\
0.81 \\
0.75 \\
0.69 \\
0.62\end{array}$ & $\begin{array}{l}0.17 \\
0.16 \\
0.15 \\
0.14 \\
0.12\end{array}$ & $\mid \begin{array}{l}0.2 \\
0.1 \\
0.1 \\
0.1\end{array}$ \\
\hline $\begin{array}{l}11 \\
12 \\
13 \\
14\end{array}$ & $\begin{array}{ll}607 x & 9.6 \\
579 x & 9.2 \\
545 x & 8.7 \\
499 x & 7.9 \\
430 x & 6.8\end{array}$ & $\begin{array}{l}729 \times 11.6 \\
696 \times 11.1 \\
655 \times 10.4 \\
600 \times 9.5 \\
518 \times 8.2\end{array}$ & $\begin{array}{l}2.26 \\
1.81 \\
1.34 \\
0.84 \\
0.84\end{array}$ & $\begin{array}{l}0.73 \\
0.62 \\
0.49 \\
0.35 \\
0.35\end{array}$ & $\begin{array}{l}1.54 \\
1.23 \\
0.91 \\
0.57 \\
0.57\end{array}$ & $\begin{array}{l}0.55 \\
0.47 \\
0.37 \\
0.26 \\
0.26\end{array}$ & $\begin{array}{l}0.11 \\
0.10 \\
0.08 \\
0.07 \\
0.04\end{array}$ & $\begin{array}{lll}0 & 1 & 1 \\
0 & .1 \\
0 & .0 \\
0 & .0\end{array}$ \\
\hline
\end{tabular}

表 2 FL7-3 Frame $\left(\sigma_{\mathrm{c}}=300 \mathrm{kgf} / \mathrm{cm}^{2}\right)$

\begin{tabular}{|c|c|c|c|c|c|c|c|c|}
\hline \multirow{3}{*}{ Story } & \multicolumn{2}{|c|}{ Steel tube of CFT column } & \multicolumn{4}{|c|}{ H-section beam } & \multicolumn{2}{|c|}{ Axial force ratio } \\
\hline & Outside column & Inside column & \multicolumn{2}{|c|}{ Outside beam } & \multicolumn{2}{|c|}{ Inside beam } & \multirow{2}{*}{$\begin{array}{l}\text { Outside } \\
\left(\mathrm{N} / \mathrm{N}_{\mathrm{u}}\right)\end{array}$} & \multirow{2}{*}{$\begin{array}{l}\text { Inside } \\
\left(\mathrm{N} / \mathrm{N}_{\mathrm{u}}\right)\end{array}$} \\
\hline & $(D \times t)$ & $(D \times t)$ & $I_{x}$ & $\mathrm{Z}_{\mathrm{p}}$ & $\mathrm{I}_{\mathrm{x}}$ & $\overline{Z_{P}}$ & & \\
\hline $\begin{array}{l}1 \\
2 \\
3\end{array}$ & $\begin{array}{ll}560 x & 8.9 \\
549 x & 8.7 \\
533 x & 8.5 \\
511 x & 8.1 \\
482 x & 7.7\end{array}$ & $\begin{array}{l}674 \times 10.7 \\
660 \times 10.5 \\
641 \times 10.2 \\
615 \times 9.8 \\
580 \times 9.2\end{array}$ & $\begin{array}{l}1.77 \\
1.59 \\
1.38 \\
1.12 \\
0.83\end{array}$ & $\begin{array}{l}0.61 \\
0.56 \\
0.50 \\
0.43 \\
0.35\end{array}$ & $\begin{array}{l}1.20 \\
1.08 \\
0.94 \\
0.76 \\
0.57\end{array}$ & $\begin{array}{l}0.46 \\
0.42 \\
0.38 \\
0.32 \\
0.26\end{array}$ & $\begin{array}{l}0.18 \\
0.16 \\
0.15 \\
0.13 \\
0.11\end{array}$ & $\begin{array}{l}0.22 \\
0.20 \\
0.18 \\
0.15 \\
0.13\end{array}$ \\
\hline $\begin{array}{l}6 \\
7\end{array}$ & $\begin{array}{ll}442 \times & 7.0 \\
377 \times & 6.0\end{array}$ & $\begin{array}{ll}531 x & 8.4 \\
454 x & 7.2\end{array}$ & $\begin{array}{l}0.51 \\
0.51\end{array}$ & $\begin{array}{l}0.24 \\
0.24\end{array}$ & $\begin{array}{l}0.35 \\
0.35\end{array}$ & $\begin{array}{l}0.18 \\
0.18\end{array}$ & $\begin{array}{l}0.08 \\
0.06\end{array}$ & $\begin{array}{l}0.10 \\
0.07\end{array}$ \\
\hline
\end{tabular}

表 3 FS15-3 Frame $\left(\sigma_{\mathrm{c}}=1200 \mathrm{kgf} / \mathrm{cm}^{2}\right)$

\begin{tabular}{|c|c|c|c|c|c|c|c|c|}
\hline \multirow{3}{*}{ Story } & \multirow{2}{*}{\multicolumn{2}{|c|}{\begin{tabular}{|l|} 
Steel tube of CFT column \\
Outside column Inside column
\end{tabular}}} & \multicolumn{4}{|c|}{ H-section beam } & \multicolumn{2}{|c|}{ Axial force ratip } \\
\hline & & & \multicolumn{2}{|c|}{ Outside beam } & \multicolumn{2}{|c|}{ Inside beam } & \multirow{2}{*}{$\begin{array}{l}\text { Outside } \\
\left(\mathrm{N} / \mathrm{N}_{\mathrm{u}}\right)\end{array}$} & \multirow{2}{*}{\begin{tabular}{|l|} 
Inside \\
$\left(\mathrm{N} / \mathrm{N}_{\mathrm{U}}\right)$ \\
\end{tabular}} \\
\hline & $(\mathrm{D} \times \mathrm{t})$ & $(D \times t)$ & $\mathrm{I}_{\mathrm{x}}$ & $\mathrm{Z}_{\mathrm{P}}$ & $I_{x}$ & $Z_{P}$ & & \\
\hline $\begin{array}{l}1 \\
2 \\
3 \\
4 \\
5\end{array}$ & $\begin{array}{l}658 \times 10.4 \\
657 \times 10.4 \\
654 \times 10.4 \\
650 \times 10.3 \\
645 \times 10.2\end{array}$ & $\begin{array}{l}783 \times 12.4 \\
782 \times 12.4 \\
779 \times 12.4 \\
774 \times 12.3 \\
768 \times 12.2\end{array}$ & \begin{tabular}{|l|}
5.16 \\
5.02 \\
4.85 \\
4.64 \\
4.40
\end{tabular} & $\begin{array}{l}1.36 \\
1.33 \\
1.30 \\
1.26 \\
1.21\end{array}$ & \begin{tabular}{|l|}
3.51 \\
3.42 \\
3.30 \\
3.16 \\
3.00
\end{tabular} & $\begin{array}{l}1.02 \\
1.00 \\
0.97 \\
0.94 \\
0.91\end{array}$ & $\begin{array}{l}0.11 \\
0.11 \\
0.10 \\
0.09 \\
0.09\end{array}$ & $\begin{array}{l}0.14 \\
0.13 \\
0.12 \\
0.12 \\
0.11\end{array}$ \\
\hline $\begin{array}{r}6 \\
7 \\
8 \\
9 \\
10\end{array}$ & $\begin{array}{l}638 \times 10.1 \\
629 \times 10.0 \\
618 \times 9.8 \\
605 \times 9.6 \\
589 \times 9.4\end{array}$ & $\begin{array}{l}760 \times 12.1 \\
750 \times 11.9 \\
737 \times 11.7 \\
722 \times 11.5 \\
703 \times 11.2\end{array}$ & $\begin{array}{l}3.48 \\
3.11 \\
2.71\end{array}$ & $\begin{array}{l}1.01 \\
0.93 \\
0.84\end{array}$ & & $\begin{array}{l}0.86 \\
0.81 \\
0.76 \\
0.70 \\
0.63\end{array}$ & $\begin{array}{l}0.08 \\
0.07 \\
0.07 \\
0.06 \\
0.06\end{array}$ & $\begin{array}{l}0.08 \\
0.08 \\
0.07\end{array}$ \\
\hline $\begin{array}{l}11 \\
12 \\
13 \\
14 \\
15\end{array}$ & $\begin{array}{ll}569 x & 9.0 \\
545 x & 8.7 \\
515 x & 8.2 \\
473 x & 7.5 \\
410 x & 6.5\end{array}$ & 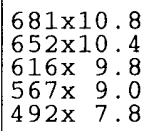 & $\begin{array}{l}2.28 \\
1.83 \\
1.35 \\
0.85 \\
0.85\end{array}$ & $\begin{array}{l}0.74 \\
0.63 \\
0.50 \\
0.35 \\
0.35\end{array}$ & $\begin{array}{l}1.55 \\
1.25 \\
0.92 \\
0.58 \\
0.58\end{array}$ & $\begin{array}{l}0.55 \\
0.47 \\
0.37 \\
0.26 \\
0.26\end{array}$ & $\begin{array}{l}0.05 \\
0.04 \\
0.04 \\
0.03 \\
0.02\end{array}$ & $\begin{array}{l}0.06 \\
0.05 \\
0.05 \\
0.04 \\
0.02\end{array}$ \\
\hline
\end{tabular}

表 4 FS7-3 Frame $\left(\sigma_{c}=1200 \mathrm{kgf} / \mathrm{cm}^{2}\right)$

\begin{tabular}{|c|c|c|c|c|c|c|c|c|}
\hline \multirow{3}{*}{ Story } & \multirow{2}{*}{\multicolumn{2}{|c|}{ Steel tube of CFT column }} & \multicolumn{4}{|c|}{ H-section beam } & \multicolumn{2}{|c|}{ Axial force ratio } \\
\hline & & & \multicolumn{2}{|c|}{ Outside beam } & \multicolumn{2}{|c|}{ Inside beam } & Outside & Insid \\
\hline & $(D \times t)$ & $(\mathrm{D} \times \mathrm{t})$ & 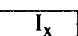 & $\mathrm{Z}_{\mathrm{P}}$ & $I_{x}$ & $\mathrm{Z}_{\mathrm{p}}$ & $\left(\mathrm{N} / \mathrm{N}_{\mathrm{u}}\right)$ & $\mathrm{N} / \mathrm{N}_{\mathrm{u}}$ \\
\hline $\begin{array}{l}1 \\
2 \\
3 \\
4 \\
5\end{array}$ & $\begin{array}{ll}516 \mathrm{x} & 8.2 \\
508 \mathrm{x} & 8.1 \\
496 \mathrm{x} & 7.9 \\
478 \mathrm{x} & 7.6 \\
453 \mathrm{x} & 7.2\end{array}$ & $\begin{array}{ll}615 \times & 9.8 \\
606 \times & 9.6 \\
591 \times & 9.4 \\
571 \times & 9.1 \\
541 \times & 8.6\end{array}$ & $\begin{array}{l}1.78 \\
1.60 \\
1.38 \\
1.13 \\
0.84\end{array}$ & $\begin{array}{l}0.61 \\
0.57 \\
0.51 \\
0.44 \\
0.35\end{array}$ & \begin{tabular}{|l|}
1.21 \\
1.09 \\
0.94 \\
0.77 \\
0.57
\end{tabular} & $\begin{array}{l}0.46 \\
0.42 \\
0.38 \\
0.33 \\
0.26\end{array}$ & $\begin{array}{l}0.08 \\
0.07 \\
0.06 \\
0.05\end{array}$ & \\
\hline $\begin{array}{l}6 \\
7\end{array}$ & $\begin{array}{ll}416 \times & 6.6 \\
358 x & 5.7\end{array}$ & $\begin{array}{l}499 \times 7.9 \\
429 \times 6.8\end{array}$ & .52 & $\begin{array}{l}0.24 \\
0.24\end{array}$ & $\left|\begin{array}{l}0.35 \\
0.35\end{array}\right|$ & 0.18 & $\begin{array}{l}0.04 \\
0.03\end{array}$ & 0.0 \\
\hline
\end{tabular}

$D$ :Diameter of steel tube $(\mathrm{mm}), \mathrm{t}$ :Thickness of steel tube $(\mathrm{mm})$,

$\mathrm{I}_{\mathrm{x}}$ :Moment of inertia $\left(\times 10^{5} \mathrm{~cm}^{4}\right), \mathrm{Z}_{\mathrm{p}}$ :Plastic modulus of $\mathrm{H}$-section beam $\left(\times 10^{4} \mathrm{~cm}^{3}\right)$ 
重による二定鉛直荷重を与えた後に、層せん断力分布が $\mathrm{A}_{\mathrm{i}}$ 值で表 される分布と一致する水平荷重 $\left(\mathrm{H}_{\mathrm{i}}, \mathrm{i}\right.$ : 柱梁接合部パネルの番号)を 単調に静載荷する。

図 9 - 図 10 は計算結果の荷重変形関係である。縦軸は水平荷重 $\Lambda$ $\left(=\Sigma \mathrm{H}_{\mathrm{i}} / \mathrm{W}, \Sigma\right.$ : 全柱梁接合部における水平荷重の和，W: 建物全重量 $)$

で、横軸は左側外柱の第 $\mathrm{i}$ 層水平変位 $\left(\mathrm{u}_{\mathrm{i}}\right)$ と建物高さ $\left(\mathrm{L}_{\mathrm{H}}\right)$ との比で
表した骨組変形である。図中の矢印は骨組内のいずれかの CFT 柱に 最初の鋼管局部座屈 (LB) あるいは鋼管亀裂 $(\mathrm{CR})$ が発生した点を示 す。図によると、いずれの骨組も各柱の変動軸力の影響と P- $\Delta$ 効果 により塑性化後の柱水平酎力が徐々に低下する挙動のため、骨組崩 壊機構に近い状態あるいは骨組崩壊機構が形成された後に骨組の復 元力低下が現われている。CFT 柱の鋼管局部座屈は最大耐力に達し
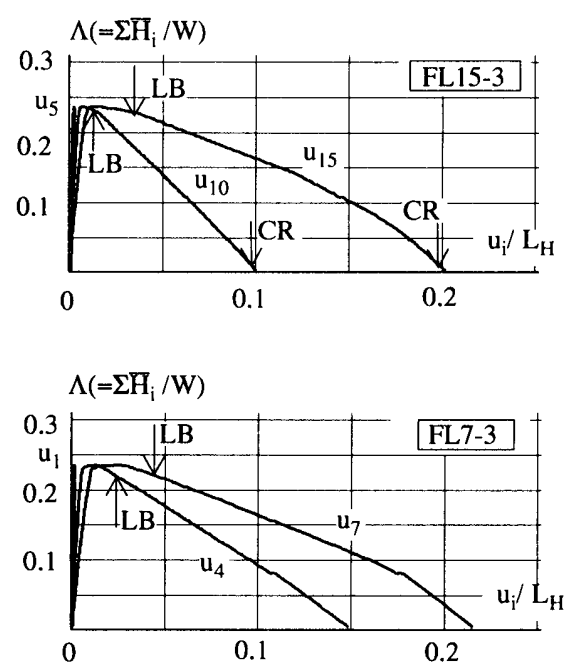

図 9 骨組の水平荷重と水平変位の関係 $\left(\sigma_{\mathrm{c}}=300 \mathrm{kgf} / \mathrm{cm}^{2}\right.$ の骨組の場合 $)$
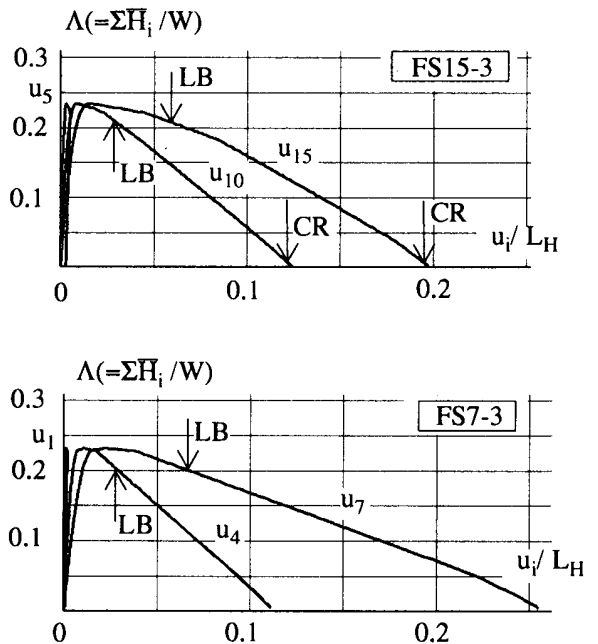

図 10 骨組の水平荷重と水平変位の関係 $\left(\sigma_{\mathrm{c}}=1200 \mathrm{kgf} / \mathrm{cm}^{2}\right.$ の骨組の場合 $)$
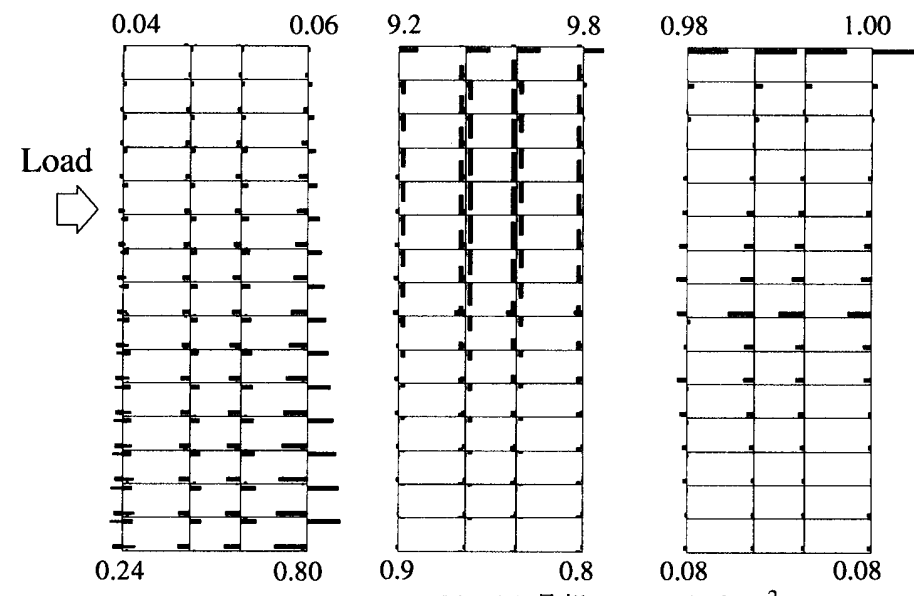

FL15-3 骨組 $\left(\sigma_{c}=300 \mathrm{kgf} / \mathrm{cm}^{2}\right)$
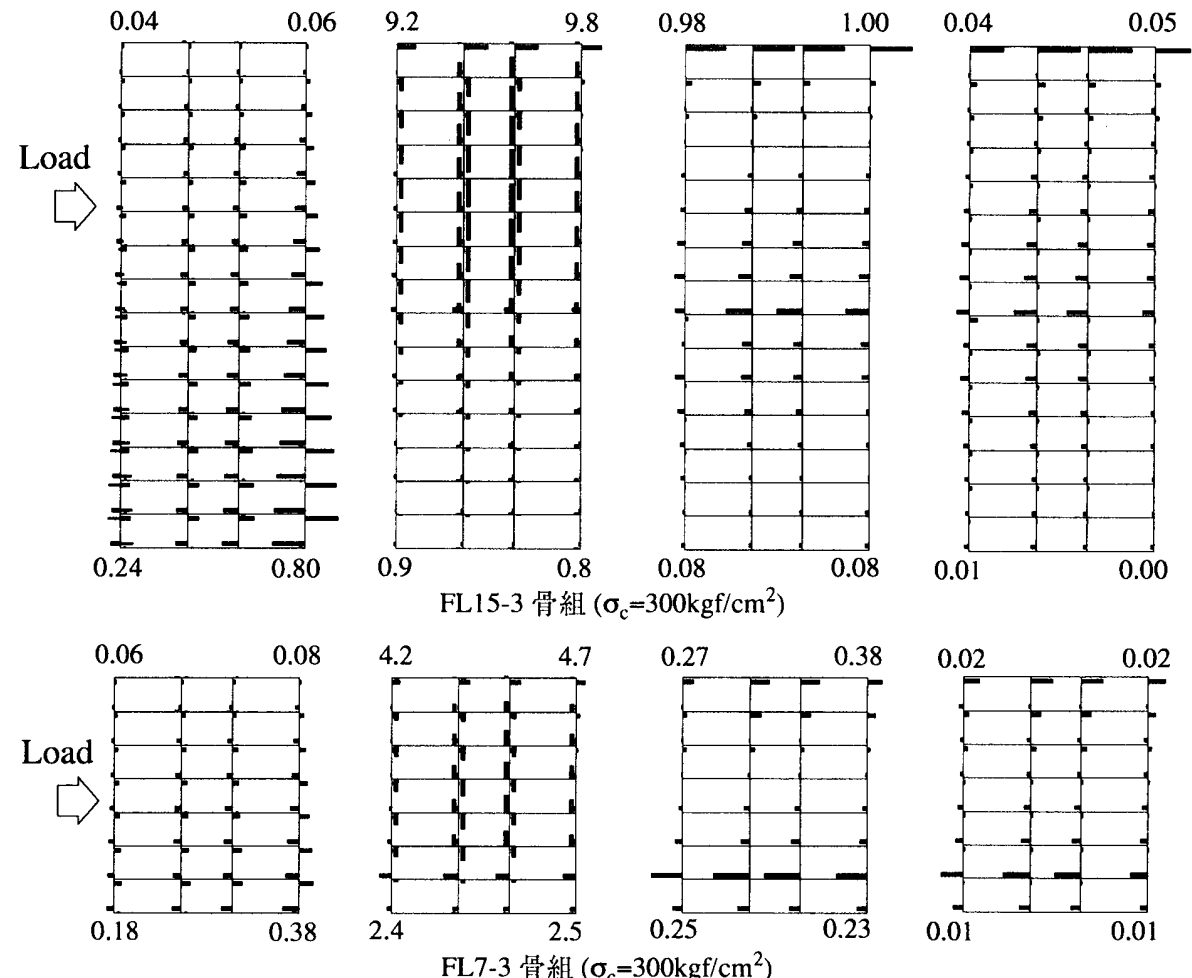

FL7-3 骨組 $\left(\sigma_{c}=300 \mathrm{kgf} / \mathrm{cm}^{2}\right)$
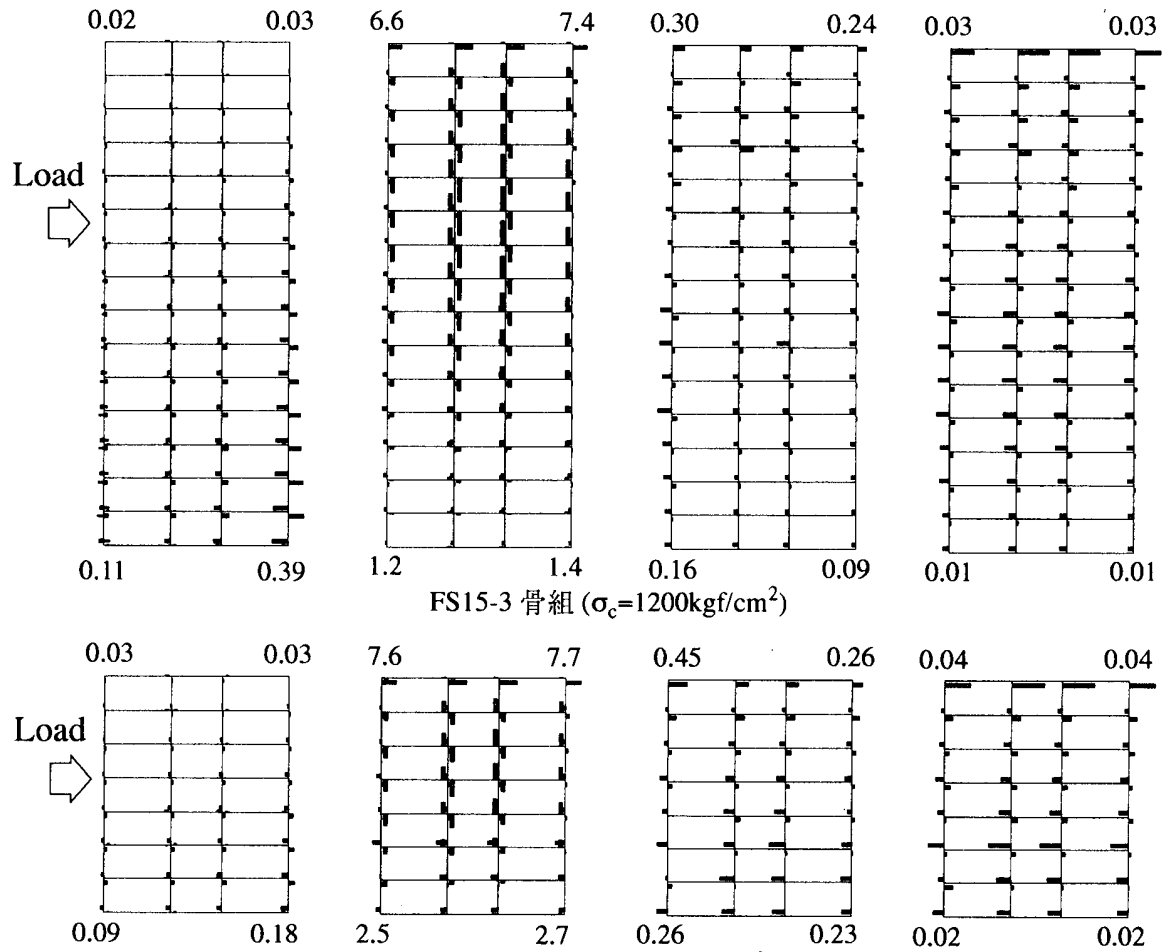

FS7-3 骨組 $\left(\sigma_{c}=1200 \mathrm{kgf} / \mathrm{cm}^{2}\right)$

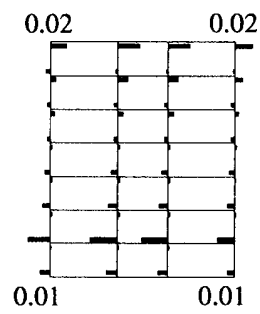

柱軸力比 $\left(\mathrm{N} / \mathrm{N}_{\mathrm{u}}\right)$

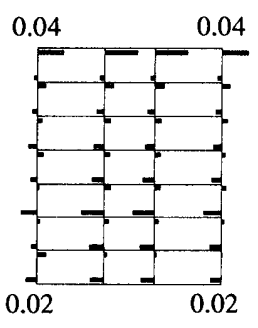

亀裂損傷率 $\left(\mathrm{D}_{\mathrm{cr}}\right)$

図 11 単調水平荷重を受ける筲組の柱軸力比と損傷率分布 
た後に発生し、鋼管亀裂は 15 層骨組 (FL15-3, FS15-3)に現われ、復 元力をほぽ失った後に第 8 層柱 (FL15-3) と第 7 層柱 (FS15-3) に発生 している。又、変形増加にともなって骨組の変形形状が変化する挙 動が現われたが、変形形状を極端に変えるまでには到らず、いずれ の骨組も第 1 次固有振動形に近い変形形状を保ったままで復元力を 失った。

図 11 は骨組復元力が設計耐力の $90 \%(\Lambda=0.225)$ まで低下した骨 組に発生した CFT 柱軸力比 $\left(\mathrm{N} / \mathrm{N}_{\mathrm{u}}, \mathrm{N}_{\mathrm{u}}=\sigma_{\mathrm{c}} \mathrm{A}_{\mathrm{c}}+\sigma_{\mathrm{u}} \mathrm{A}_{\mathrm{s}}\right)$ 、各柱梁弾塑性と ンジの塑性変形率 $\left(\phi / \phi_{\mathrm{u}}\right)$ 、鋼管の局部座屈損傷率 $\left(D_{\mathrm{lb}}\right)$ 、亀裂損傷率 $\left(\mathrm{D}_{\mathrm{cr}}\right)$ を表したものである。各值を部材端部に材軸直交方向に示す太 線の長さで表わす。図中の数值は太線の値を説明したもので、最下 層柱脚と最上層柱頭の值である。 $\mathrm{N} / \mathrm{N}_{\mathrm{u}}$ 図の太線のうち太い方は圧 縮軸力、細い方は引張軸力の最大值を示す。 $\mathrm{D}_{\mathrm{lb}}$ と $\mathrm{D}_{\mathrm{cr}}$ 值は (3) 式と (5) 式に示した各々鋼管の局部座屈発生条件と亀裂発生条件を基準 にその損傷割合を表し、各值を(17) 式と (18) 式で与える。

$$
D_{\mathrm{lb}}=\left(\varepsilon_{\mathrm{t}}-\varepsilon_{\mathrm{c}}\right) / \varepsilon_{\mathrm{lb}}
$$

但し、 $\varepsilon_{\mathrm{t}}-\varepsilon_{\mathrm{c}}$ : 発生した鋼管の引張歪と压縮歪の差、 $\varepsilon_{\mathrm{lb}}\left(=14 \sigma_{\mathrm{u}} / \mathrm{E}\right)$ : 鋼管局部座屈が発生する歪振幅である。

$$
\mathrm{D}_{\mathrm{cr}}=\left(\Sigma \Delta \varepsilon_{\mathrm{TC}}+\Sigma \Delta \varepsilon_{\mathrm{T}}\right) / \alpha \varepsilon_{\mathrm{f}}
$$

但し、 $\Sigma \Delta \varepsilon_{\mathrm{TC}}+\Sigma \Delta \varepsilon_{\mathrm{T}}$ ：鋼管の累積引張塑性歪、 $\Delta \varepsilon_{\mathrm{TC}}, \Delta \varepsilon_{\mathrm{T}}$ ：各々 $\Delta \mu_{\mathrm{TC}}$, $\Delta \mu_{\mathrm{T}}$ による鋼管の引張塑性昰増分、 $\alpha \varepsilon_{\mathrm{f}}$ : 鋼管亀裂が発生する累積引 張塑性歪、 $\varepsilon_{\mathrm{f}}(=0.20)$ : 鋼管の破断伸び、 $\alpha(=-0.3 p+5.0)$ : 定数である。 全ての骨組は梁降伏型骨組となることを条件に設計したため、主 たる塑性変形は各層の $\mathrm{H}$ 形鋼梁に生じている。しかし、柱変動軸力 の影響と CFT 柱の復元力は終局曲げ耐力 $\left(\mathrm{M}_{\mathrm{u}}\right)$ よりも低い值の降伏 曲げ耐力 $\left(\mathrm{M}_{\mathrm{y}}\right)$ で煀性低下することが原因となって、 $\mathrm{H}$ 形鋼梁のみ

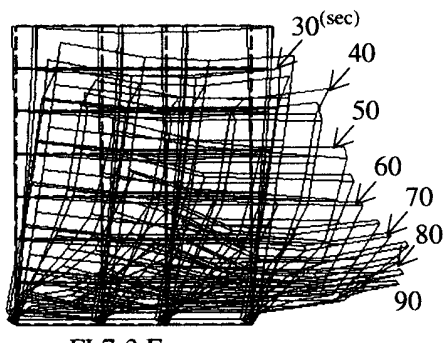

FL7-3 Frame

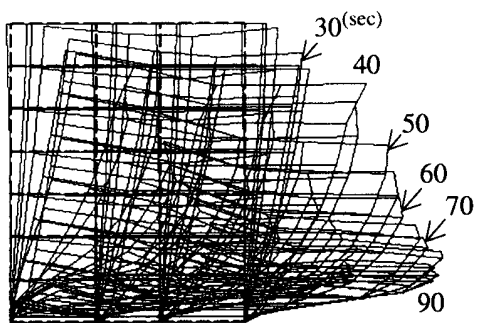

FS7-3 Frame

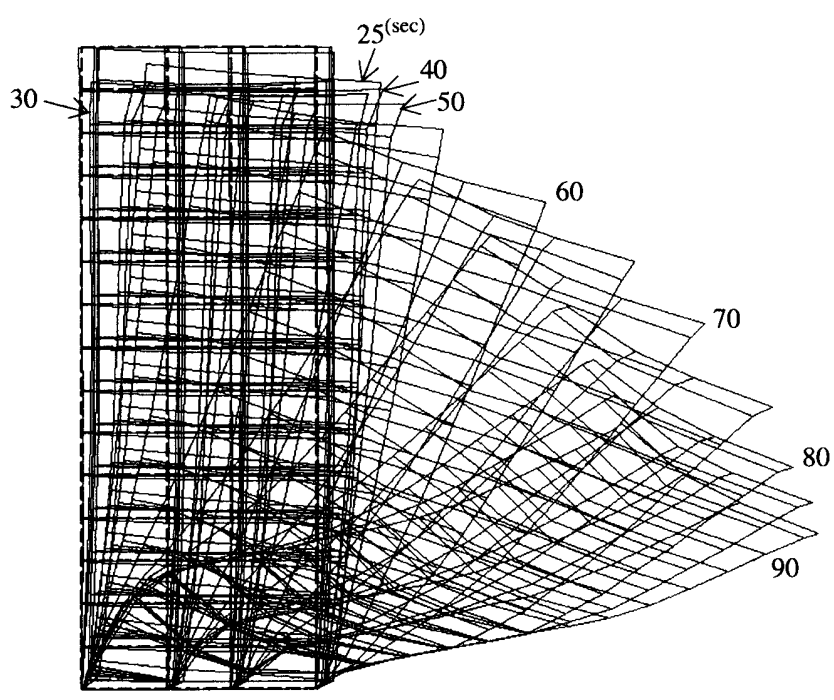

FL15-3 Frame
でなく同時に一部の CFT 柱にも塑性変形が現われている。又、超高 強度コンクリート充填鋼管柱のCFT 骨組 (FS15-3, FS7-3) では骨組全 体にほぼ一様に損傷率 $\mathrm{D}_{\mathrm{Ib}}, \mathrm{D}_{\mathrm{cr}}$ が分布しているのに対し、初期軸力 比と変動軸力比が高い普通強度コンクリート充填鋼管柱の CFT 骨組 (FL15-3, FL7-3) では一部の層への損傷集中が現われ、超高強度コン クリート充填鋼管柱の骨組挙動と異なる。

\section{5. 激震動応答による骨組崩壊}

\section{1 骨組崩壊解析法}

増分型振動方程式 ((16) 式)を Newmark $\beta$ 法 $(\beta=1 / 4)$ で解いて、激 震動応答によるCFT 骨組の崩壊挙動を計算し、崩壊過程と崩壊を支 配するCFT 柱の損傷を示す。

計算するCFT 骨組には次の条件を与える。

i) 各柱梁接合部パネルに集中させた骨組の質量を柱梁接合部パネ ル内に一様分布させて回転慣性を表す。

ii) 骨組の減衰には Rayleigh 型の粘性減衰を仮定し、第 1 次及び 第 2 次の減衰定数を $2.0 \%$ とする。この粘性減衰は CFT 柱に鋼管刍 裂が発生した後も不変とする。

また、崩壊挙動を解析するため次の条件を与えた。

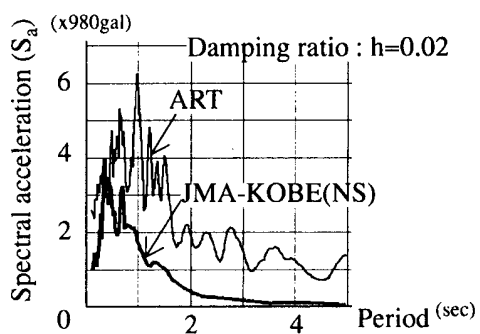

図 12 入力地震動 (ART, JMA-KOBE) の加速度応答スペクトル $\left(\mathrm{S}_{\mathrm{a}}\right)$

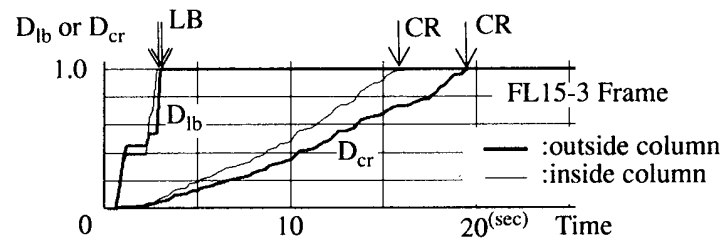

四 $13 \mathrm{CFT}$ 柱の局部座屈損傷率 $\left(\mathrm{D}_{\mathrm{b}}\right)$ と 亀裂損傷率 $\left(\mathrm{D}_{\mathrm{cr}}\right)$ の時刻歴

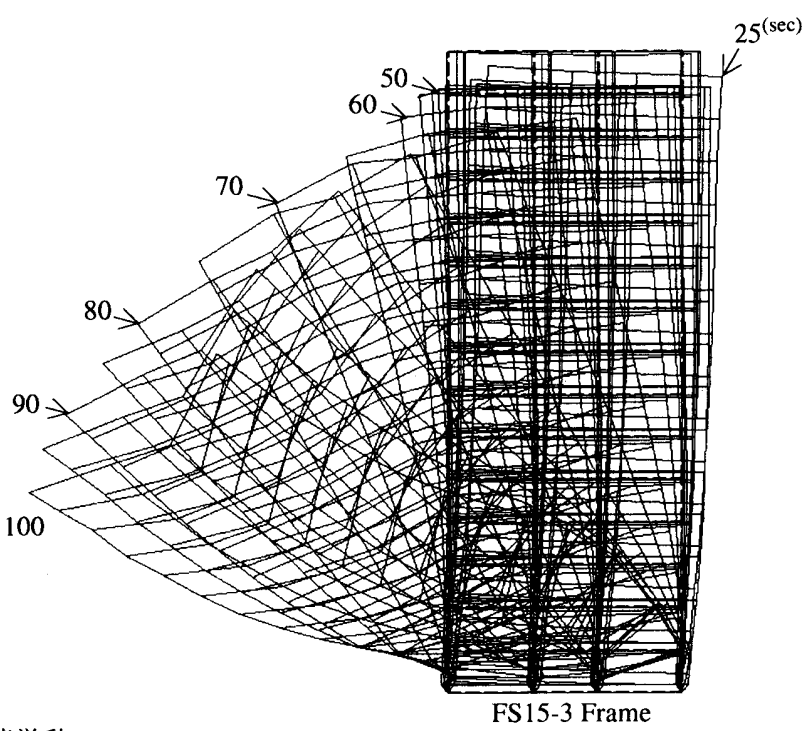


i) CFT 柱に鋼管亀裂が発生すると柱の復元力と剛性は時間とと もに直線的に低下し 0.1 秒間で完全に失われる。これはCFT 柱の動 載荷実験 ${ }^{2)}$ で瞬間的に発生した鋼管亀裂とその場合の CFT 柱挙動を 想定したものである。

ii) 柱梁接合部パネルが落下し、その下の柱梁接合部パネルと衝 突する場合の衝突力は柱梁接合部パネルの圧縮荷重に対する静的復 元力で近似し、この復元力特性は CFT 短柱圧縮試験值 ${ }^{3)}$ 基に Bi-linear モデルで表す。又、衝突後両柱梁接合部パネル間には水平 方向に摩擦係数 0.1 で表される摩擦力が㗢くものとする。

なお、応答計算の増分時間は $10^{-4}$ 秒とし、計算精度を Energy balance 式で判断した。その誤差が全増分ステップで地震入力エネルギ 一の $10^{-3}$ 倍以下となることを条件とし、これを確認した。

入力地震動には CFT 骨組の崩壊を解析するのに必要な強さと継続 時間を与えるため、即ち、骨組が塑性化し固有周期が変化した後も 強い地震応答が継続する地震波を与えるため、その地震応答スペク トルを図 12 に示す模擬地震動 (ART) を作成しこれを使用した。こ の入力地震動は水平動成分のみで上下動成分はこれに含まれてな w。

\section{2 骨組崩壊の計算結果}

激震動応答によるCFT 骨組崩壊の計算結果によると、CFT 柱の 鋼管局部座屈が発生するまでは亀裂損傷率 $\mathrm{D}_{\mathrm{cr}}$ はいずれも低い值を 示し鋼管亀裂は発生していない。この挙動を説明するため FL15-3 骨組で最初に鋼管亀裂が発生した第 1 層柱脚の損傷率時刻歴を図 13
に示す。四 13 は鋼管局部座屈損傷率と亀裂損傷率間の関連を表し たもので、図中の矢印 (LB, CR) は鋼管の局部座屈と龟裂が発生した 点である。図に示すように鋼管局部座屈が発生すると象裂損傷率の 増加が顕著となる。その後刍裂損傷率が単調に増加し亀裂発生に到 る。骨組のいずれかの柱に最初の亀裂が現われるとその層の他の柱 に連鎖的に亀裂が発生するとともに、局部座屈と亀裂発生の範囲が 他の層の柱にも拡がっている。同時に急激な骨組の落下が始まり柱 梁接合部パネルの衝突を繰り返しながら骨組は崩壊する。

図 14 は 5.0 秒間罊で表したCFT 骨組の応答変形で、骨組の崩壊 過程を示したものである。又、骨組の変形前の状態を破線で示し、 地震応答の経過時間を図中の数字で示す。この図の変形は単に柱梁 接合部パネルの中心を結んだもので、柱梁接合部パネルの回転、弾 塑性ヒンジの回転等は表されてない。図に示すように第 1 層のCFT 柱に亀裂が発生した後、骨組の応答変形形状が極めて複雑に変化し ながら骨組崩壊が進行する挙動となっている。CFT 柱の鋼管局部座 屈と亀裂はいずれの骨組も最初第 1 層柱に発生したが、これらの柱 挙動を図 15- 図 17 に示す。図中 $N_{\mathrm{o}}$ は初期軸力で、 $\mathrm{M}_{\mathrm{uo}}$ は $\mathrm{N}_{\mathrm{o}}$ に対 する終局曲げ耐力である。図 15 は各柱脚の復元力で、図の細線は 比較のために変動軸力がないとした場合の值を示したものである。 中柱に比較して外柱では変動軸力が大きく、この影響を受けて極め て複雑な復元力特性を示している。又、各柱の変動軸力と N-M 関係 を表したのが図 16 と図 17 であるが、この図から柱変動軸力が各柱 毎に大きく異なり、この柱変動軸力によって各 CFT 柱の復元力が強 く支配される挙動を見ることができる。
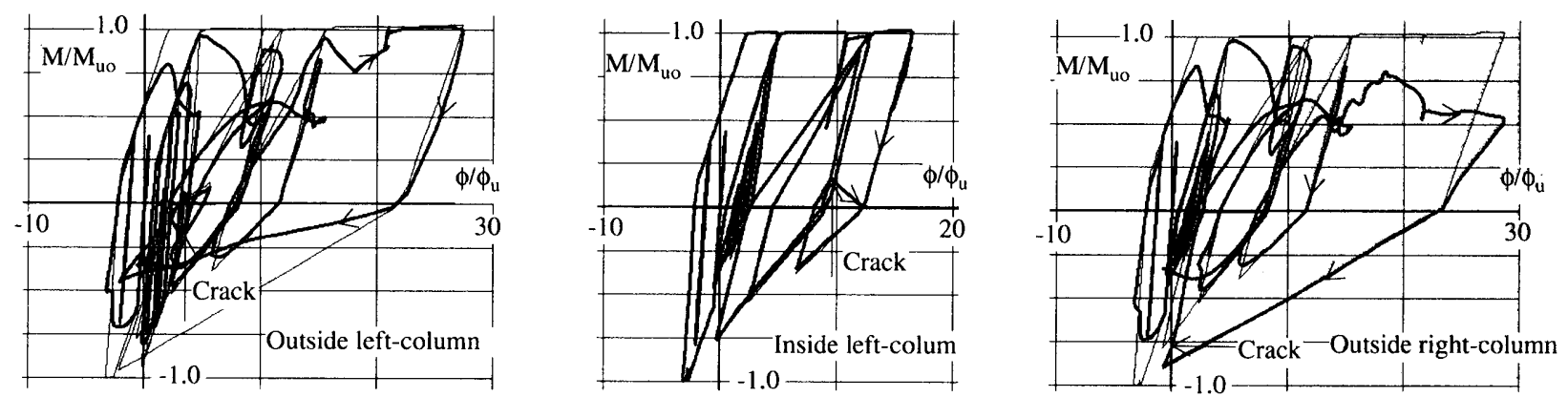

図 15 第 1 層柱脚の復元力特性 (FL15-3)
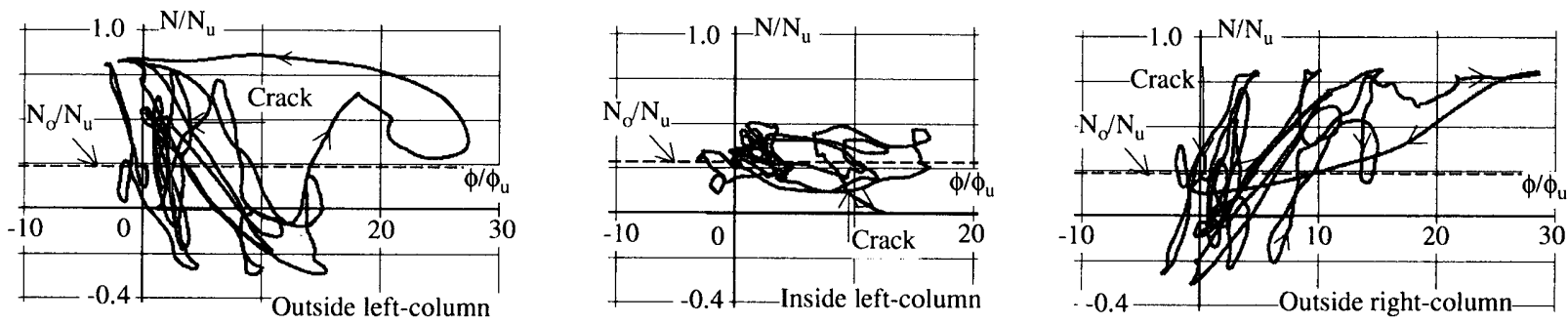

図 16 第 1 層柱の変動軸力 (FL15-3)
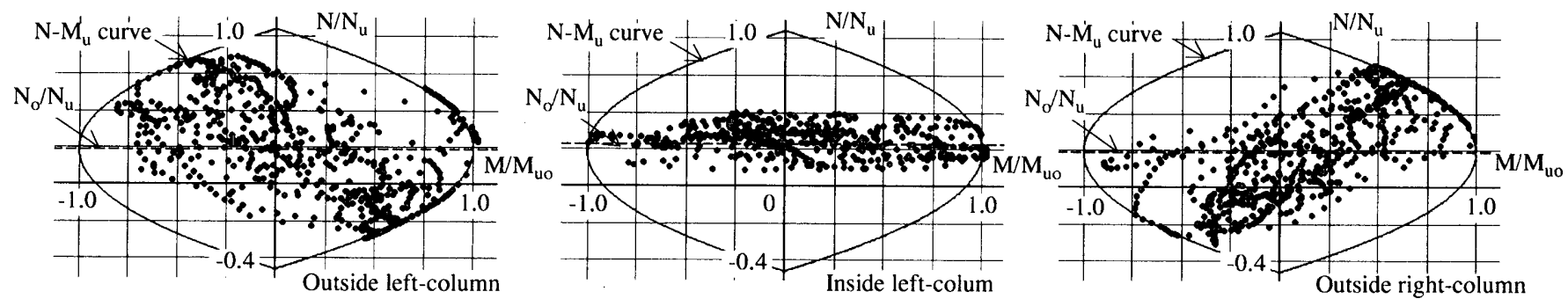

図 17 第 1 層柱脚の N-M 関係 (FL15-3) 

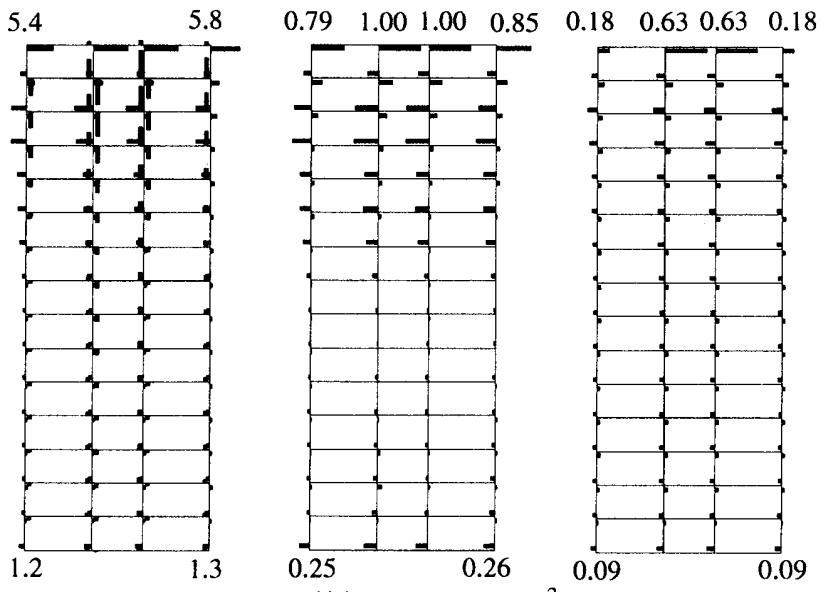

FL15-3 骨組 $\left(\sigma_{\mathrm{c}}=300 \mathrm{kgf} / \mathrm{cm}^{2}\right)$
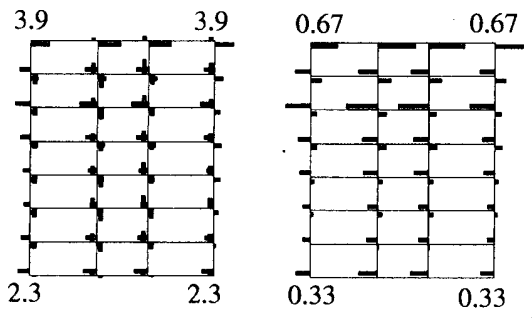

FL7-3 骨組 $\left(\sigma_{\mathrm{c}}=300 \mathrm{kgf} / \mathrm{cm}^{2}\right)$

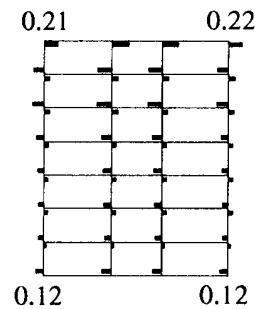

0.12

塑性変形率 $\left(\phi / \phi_{\mathrm{u}}\right)$

局部座屈損傷率 $\left(\mathrm{D}_{\mathrm{lb}}\right)$

亀裂損傷率 $\left(D_{\mathrm{cr}}\right)$

図 18 強震記録の地震動 (JMA-KOBE) を受ける骨組の塑性変形と損傷率分布
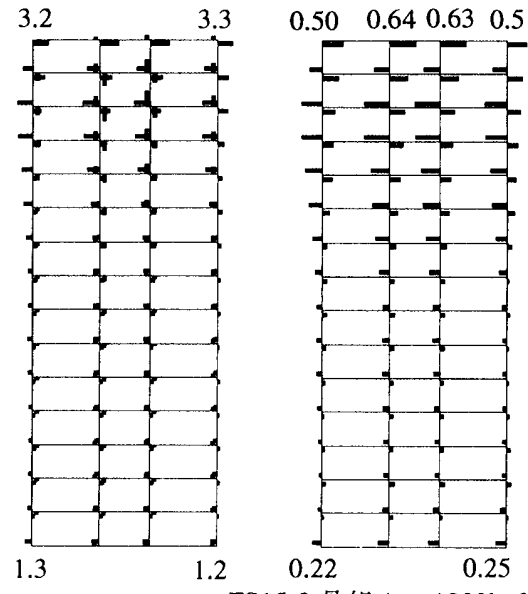

FS $15-3$ 骨組 $\left(\sigma_{\mathrm{c}}=1200 \mathrm{kgf} / \mathrm{cm}^{2}\right)$
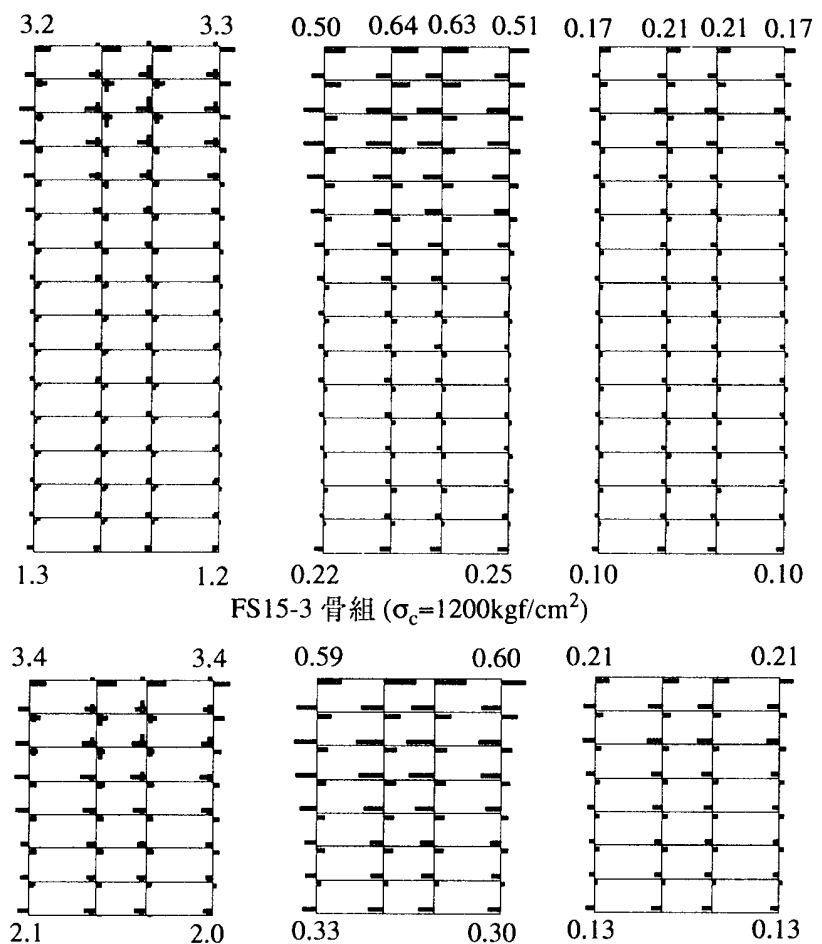

FS7-3 骨組 $\left(\sigma_{\mathrm{c}}=1200 \mathrm{kgf} / \mathrm{cm}^{2}\right)$

塑性変形率 $\left(\phi / \phi_{\mathrm{u}}\right) \quad$ 局部座屈損傷率 $\left(\mathrm{D}_{\mathrm{lb}}\right)$ 龟裂損傷率 $\left(\mathrm{D}_{\mathrm{cr}}\right)$

部座屈が発生し $\left(\mathrm{D}_{\mathrm{lb}}=1.0\right)$ 、亀裂損傷率も最大で $\mathrm{D}_{\mathrm{cr}}=0.63$ と高い值 を示している。即ち、記録された地震動を対象にしても、極めて強 い地震動をうける場合、骨組崩壊につながる CFT 柱の鋼管局部座屈 及び鐥管亀裂が発生する可能性を無視できない。

\section{7. 結論}

i) CFT 柱の無次元復元力モデルを用いた CFT 多層骨組の激震動 応答及び骨組崩壊挙動の数值解析法を導き、設計条件の異なる CFT 多層骨組の激震動応答及び骨組崩壊挙動を計算した結果、本解析法 の有效性が確かめられた。

ii) CFT 多層骨組の損傷尺度として鋼管局部座屈損傷率と龟裂損傷 率を導入し数值解析結果の地震応答及び骨組崩壊挙動を検討した結 果、 CFT 柱の鋼管局部座屈が骨組崩壞に結び付く要因となる結果が 得られた。

\section{参考文献}

1) 日本建築学会: 構造物の崩壊解析 応用編、応用力学シリーズ 7, 1999.6. 2) 最相元雄, 光成和昭 : 超高強度コンクリート充填鋼管せん断曲げ柱の終 局挙動に関する実験的研究, 日本建築学会構造系論文集, 第 520 号, 1999.6 .

3) 最相元雄, 安部貴之, 中矢浩二：超高強度コンクリート充填鋼管柱の終局 曲け耐力に関する研究, 日本建築学会構造系論文集, 第 523 号, 1999.9.

4) 最相元雄, 松山輝男: コンクリート充填鋼管柱の鋼管龟裂と累皘塑性変形 能力に関する研究, 日本建築学会椪造系論文集, 第 528 号, 2000.2.

5) 最相元雄, 辻大介, 西元洋一: コンクリート充填鋼管柱の復元力特性と復 元力モデルに関する研究, 日本建築学会構造系論文集, 第 531 号, 2000.5.

6) 最相元雄, 光成和昭, 松山輝男, 辻大介, 平山洋介: コンクリート充填鋼管 柱の動的復元力モデルの提案, 鋼構造年次論文報告集, 第 7 巻, 1999.11 .

7) 桑村仁, 佐々木道夫, 加藤勉 : 降伏耐力のばらつきを考虑した全体崩壊メ カニズム骨組の設計, 日本建築学会構造系論文集, 第 401 号, 1989.7.

8) 最相元雄, 松山輝男, 須田量哉: 動的変動軸力を受ける鉄筋コンクリート せん断曲げ柱の復元力モデルに関する実験的研究，構造工学論文集，第 45B 号, 1999.3.

9) 梅村魁編著 : 鉄筋コンクリート建物の動的耐震設計法・続 ( 中低層 ), 技 報堂出版, 1982 . 